\title{
Foliar nutrition of date palm: advances and applications. A review
}

\author{
Hussein J. Shareef ${ }^{1 *}$, Ibtihaj H. Al-Tememi², Gholamreza Abdi ${ }^{3}$ \\ ${ }^{1}$ Department of Date Palm Research Center, University of Basrah, Basrah, Iraq \\ ${ }^{2}$ Department of Horticulture and Landscape Design, College of Agriculture, \\ Basrah University, Basrah, Iraq \\ ${ }^{3}$ Department of Biotechnology, Persian Gulf Research Institute, Persian Gulf University, Bushehr, Iran
}

\begin{abstract}
Shareef, H.J., Al-Tememi, I.H., AbDi, G., 2021. Foliar nutrition of date palm: advances and applications. A review. Folia Oecologica, 48 (1): 82-99.

Foliar fertilization is one of the crucial ways for continued cultivation of date palm, obtaining the best results of growth and production, in addition to the possibility to reduce damage from abiotic stress. Although subjected date palm to an annual fertilization program, it faces some challenges, including low soil availability for nutrients, dryness of the soil surface, low root activity in the breeding period, soil alkalinity, as well as water scarcity in areas of cultivation, and symptoms of deficiency of some elements. This review attempts to shed light on the importance of using leaf fertilization, demonstrating the successful technique and positive results, and proving the ability of date palm cells to absorb nutrients, similar to other trees, and interact with chemical and biological fertilizers. Besides, the leaflet's possibility of absorbing various nutrients, chelated iron, biostimulants, antioxidants, and nano-fertilization, are presented.
\end{abstract}

\section{Keywords}

date palm, foliar nutrition, leaf morphology, leaf anatomy, Phoenix dactylifera $\mathrm{L}$.

\section{Introduction}

Plant development and advancement generally rely upon the mix and grouping of mineral supplements accessible in the soil. Plants frequently face critical difficulties in getting sufficient flexibility of these supplements to satisfy the needs of fundamental cell measures because of their relative idleness. Inadequacy of any of them may bring about diminished plant profitability or potential ripeness. Indications of supplement inadequacy may incorporate hindered development, the demise of plant tissue, or yellowing of the leaves brought about by a diminished chlorophyll creation, a pigment required for photosynthesis. Supplement lack can significantly affect agribusiness, bringing about decreased harvest yield or diminished plant quality. Nutrient deficiencies can also reduce overall biodiversity because plants act as producers that support most food webs (Morgan and ConNOLly, 2013).

Many factors determine how much a plant needs nutrients and how much the soil can provide the plant with nutrients. Three soil properties as most important concerning any plant response-related functions are; soil $\mathrm{pH}$ (to regulate nutrient availability), texture (to regulate water transmission properties and fixation and release of nutrients), and organic matter (to realize the cascading effect on the whole range of soil physical as well chemical properties, including the biological properties), and above all, plant traits as well (nutrient efficient and nutrient responsive both) (COMERFORD, 2005).

*Corresponding author:

e-mail: hussein.shareef@uobasrah.edu.iq 
Notwithstanding, the root isn't the main organ that is associated with the absorption of nutrients. The foliage, including leaves, stem, inflorescence, and organic products, can likewise assimilate supplement nutrients (Oosterhuis, 2009). Foliar nutrients are an essential indicator of field farming's evolution, as it is one of the modern methods of high economic efficiency (ALSHAAL and El-RAMADY, 2017).

The efficacy of nutrients is governed by spray formulation's physicochemical properties such as $\mathrm{pH}$, surface tension, polarity, additives (surfactants, humectants, spreader/stickers, etc.), molecular size, ionic charge, and solubility in spray fluid. Characteristics of the species and the environment such as humidity (SCHÖNHERR and SCHREIBER, 2004), temperature (ZHANG and Brown, 1999), light (Abadia, 1992; ÁlvarezFERNÁNDEZ et al., 2004), and wind in which the plant is grown affect the rate of foliar uptake (DorDAS, 2008). Finally, the plant factors like a physical and physiological characteristics (chemical composition of the leaf such as cuticle composition, source/sink status and leaf expansion affect absorption, distribution, and penetration availability of foliar-applied nutrients of a plant), phonological stage (leaf age, leaf homogeneity) (ZHANG and BROWN, 1999) morphological traits (leaf shape, presence of hairs, presence of discontinuities (lenticels, cracks...), plant architecture (canopy architecture such as new growth, presence of reproductive structures, presence of floral or leaf buds that have a determinative effect on spray retention and penetration), epidermal systems such as stomata, cuticle thickness, stomatal distribution and density, leaf surface architecture, leaf angle, and orientation, canopy surface area, characteristics of the plant surface, leaf surface chemistry and mobility of nutrient within the part system also determine foliar nutrient uptake efficiency (ZHANG and Brown, 1999; Bringe et al., 2006; FERnÁNDEZ and Brown, 2013). The leaf's physiological state at the time of spraying and plant metabolic activity can alter demand and source: sink dynamics, availability of substrate and energy for absorption and assimilation, uptake rate, mobilization assimilation, and remobilizations of nutrients.

\section{Foliar nutrition of date palm}

Date palm (Phoenix dactylifera L.) $(2 \mathrm{n}=36)$ is a dioecious perennial tree extensively cultivated in subtropical regions, including the Middle East and North Africa (IBRAHIM, 2018). One of the primary essential tools for productive and sustainable management of crops worldwide is foliar fertilization. Target orientation and environmentally friendly properties are the most important reasons for foliar fertilization over soil fertilization. Foliar fertilizer is a vital device for the practical and gainful administration of yields and is of considerable commercial significance around the world (FAGERIA et al., 2017). Roots retain water and mineral supplements from the soil transported through the xylem to the leaf. In the leaf, these supplement components are absorbed into different natural compounds by biochemical procedures, for example, photosynthesis and related processes. These natural compounds are then transported from the leaf (source) to other plant organs (sink, for example, roots, creating young leaves, blooms, and natural products (ÖRDÖG and MOLNÁR, 2011).

Foliar spraying is a new process and not essential in feeding date palm because it helps solve low growth and productivity and environmental issues such as drought, salinity, and high temperatures. Foliar technics used to reduce saltwater damage (SHAREEF, 2016). Expanding the use of the foliar technic is a modern method for improving date palm culture. Besides, it provides new opportunities for reviving date palm in areas exposed to harsh environmental conditions that hinder date palm cultivation's success. Therefore, this review attempts to shed light on the importance of using leaf fertilization as a successful technique giving positive results and proving the ability of date palm cells to absorb nutrients, similar to other trees, and interact with chemical and biological fertilizers.

\section{Date palm leaf morphology}

Date palm leaves, popularly called fronds, are pinnate, compound leaves spirally arranged around the stem's top (meristem). In maturity, leaves are about $4 \mathrm{~m}$ in length, with a range of $3-6 \mathrm{~m}$ and $0.5 \mathrm{~m}$ wide at the focal midrib that limits the two leaves closest (Lово et al., 2014). The foliage of the date palm is long and broad dark green. The date palm leaf consists of two parts; the blade and the petiole; the leaf blade consists of three parts; pinnae, spines, and rachis; the petiole consists of a rachis base and fiber sheath (ZAID and ARIAS-JIMÉNEZ, 2002) (see Fig. 1). The pinnae (leaflet) represents the target area using a foliar spray, especially their lower surfaces. The number of stomata is more significant on the lower body (see Fig. 2). Besides, the cuticle is thinner, which makes the foliar-spraying process more effective (see Fig. 3). The quantity of leaves created every year differs from 10 to 26 and a mature palm may have from 100 to 125 leaves. Leaves stay appended to the tree following their senescence and must be physically pruned (AL-YAHYAI and Manickavasagan, 2012). The morphology of date palm leaves encourages foliar fertilization because it is a large total vegetative area to the plant's size.

\section{Anatomical characteristics of date palm leaflet}

A date palm leaflet comprises the accompanying parts in cross-section and includes the cuticle, epidermis, mesophyll, and vascular tissue. The cuticle covering elevated leaf parts is an extra-cellular layer consisting of a biopolymer framework with wax impregnated into (intracuticular) or overlaying (epicuticular wax) the surface (FERNADÉZ et al., 2015). On the inner side, a waxy substance called cutin is integrated with polysaccharide material from the epidermal cell wall, which is primarily composed of cellulose, hemicellulose, and gelatin (XU et al., 2012). Subsequently, the cuticle skin itself can be considered as a 'cutinized' cell wall; the heterogeneous 


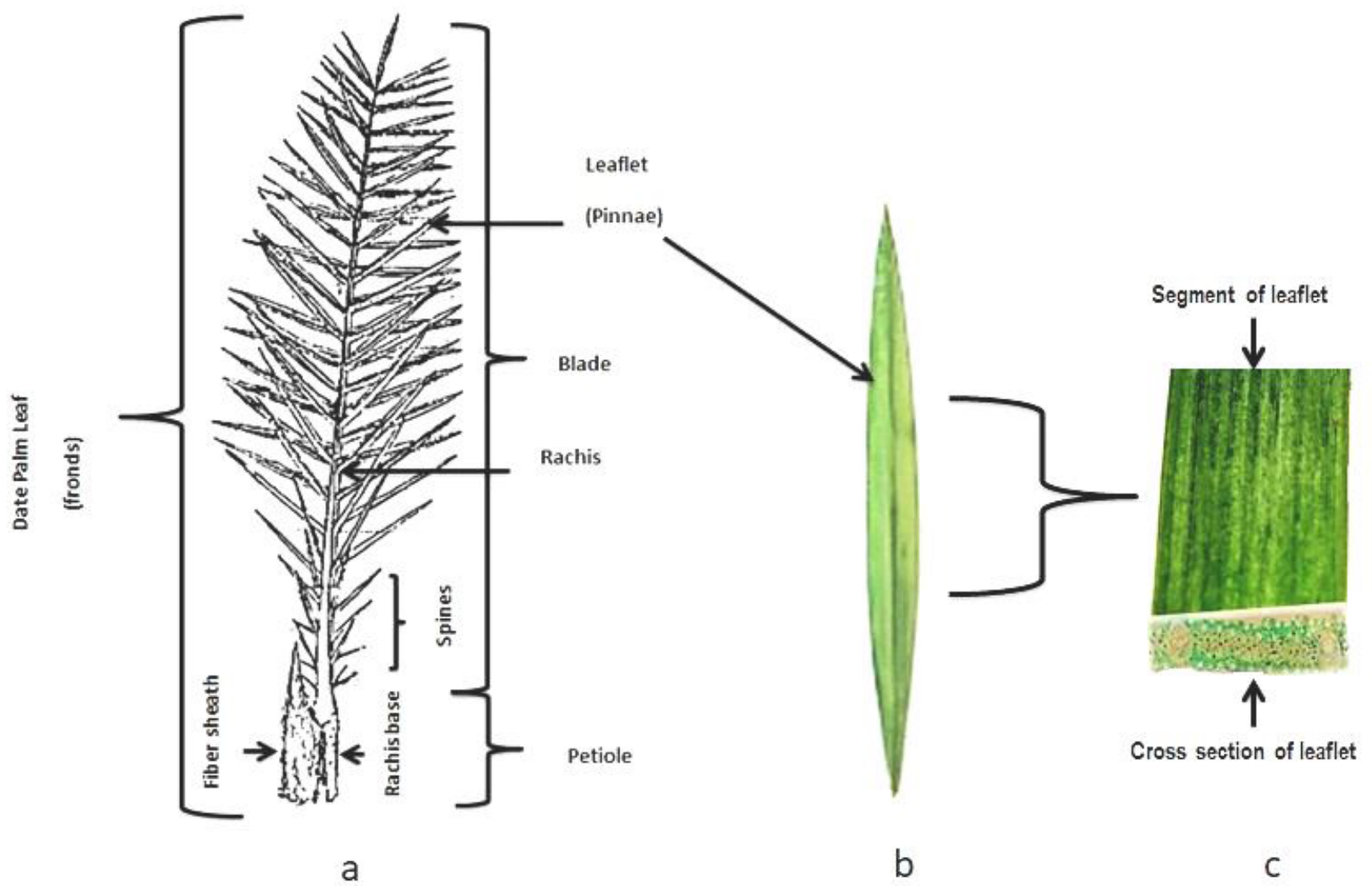

Fig. 1. The morphology of date palm leaf (a) from (ZAID and AriAs-JimÉNEZ, 2002), (b) Pinnae (leaflet), (c) cross-section of a leaflet. Photo by authors.

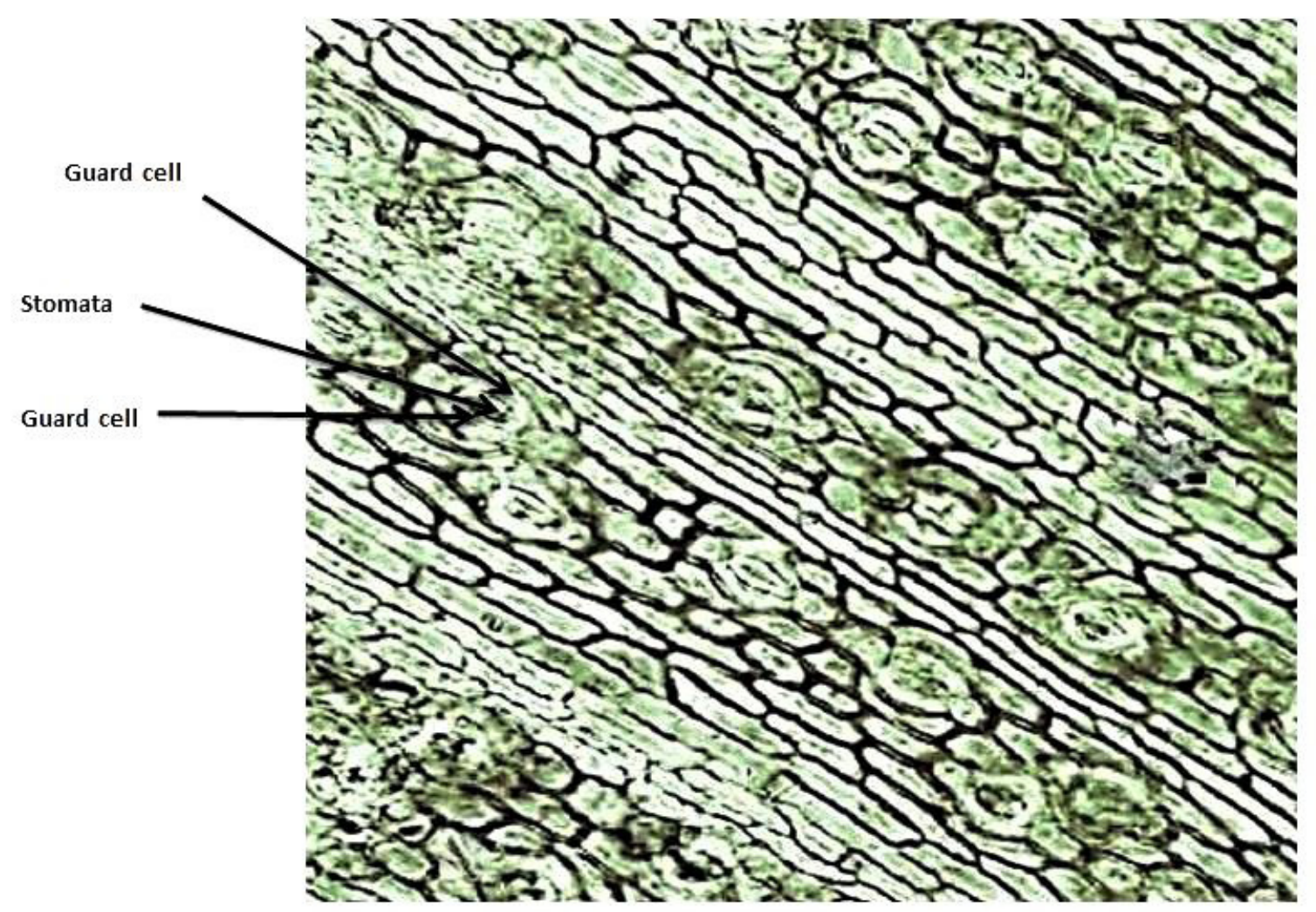

Fig. 2. A lower surface of date palm leaflet (stomata). Photo by authors. 
nature of this layer has a physiologically-vital association with the underlying cell wall (DomínGUEZ et al., 2011). A cross-section of the date palm leaflet shows no difference from a cross-section of other plant leaves. The thickness of the cuticle layer in the date palm leaflet is close to that of other plants that regularly are given foliar fertilization, such as citrus. The thickness of the cuticle in date palm ranges from 3-7 $\mu \mathrm{m}$ in various varieties (AlnaJjar and AlHamD, 2016).

In contrast, the thickness of the cuticle in other plants is $2-10 \mu \mathrm{m}$ (LeQueu et al., 2003), and the cuticle layer's thickness 4-5 $\mu \mathrm{m}$ in citrus (De Paula et al., 2019). The epidermis consists of a single row of non-specialized monocytes containing a living protoplast. No chloroplasts, but having other plastids with a few grana. The skin surrounding the top, upper epidermis, and lower epidermis surrounded by the cuticle is a single row of cells whose function is to protect the internal tissue. The skin also contains stomata, which consists of thick-walled cells connected to the air chambers. The stomata are abundant in the upper part of the leaf (upper or ventral surface), 182 stomata per $\mathrm{mm}^{2}$ compared to the lower body (dorsal) 166 stomata per $\mathrm{mm}^{2}$ (ABBAs, 2004) (see Fig. 2). The number of stomata per unit area does not differ from that of other plants. OBIREMI and Oladele (2001) found that the number of stomata in a plant of Citrus limon was 188 per mm2.

The mesophyll is the tissue trapped between the upper and lower bodies. It is not distinguished into a palisade and a spongy layer at date palm. The middle tissue contains many green plastids (DAVOodi et al., 2002). Vascular tissue consists of a group of vascular bundles spread in leaf veins and is more extensive in the petiole and surrounds each top and bottom. Sclerenchyma tissue consists of fiber cells with thick walls responsible for strengthening the leaf, divided into xylem and phloem (see Fig. 3). Xylem is near the top surface of the leaflet and is composed of parenchyma cells and follicles. Xylem is of two types protoxylem and metaxylem. Protoxylem is found in new leaves and appears in small circles in the leaflet's cross-section, while large rings are known as metaxylem and found in adult leaves (ZAID and Hughes, 1996). Phloem consists of small parenchyma cells and mucous tubes located at the bottom of the leaflet. The leaflet of date palm also contains the bundle sheath consisting of thin-walled parenchyma cells, including green plastids (DoAigeY et al., 2013).

\section{The mechanism of foliar absorption of nutrients}

The cuticle is composed mainly of the epicuticular wax layer, the cuticular proper (intracuticular waxes and cutin/ cutan), and the cuticular layer (polysaccharide material and cutin/cutan). The exposed aerial surface is a complex of the specialized cell of different layers which help plant tolerate unfavorable condition such as herbivory, wind, temperatures, irradiation, vapor pressure deficits, dust, rain, aerial pollutants, drought condition (restrict the loss of nutrients, metabolites, water, and passage of water vapor and gases) physical damage, insect attack, and bacterial and fungal pathogens. Understanding the physiochemical attributes of plant surfaces and the penetration processes of nutrients into the plant can improve foliar fertilization's efficacy and reproducibility.

The nutrient absorption process's success through the leaf surface depends on forming a thin layer of solution wetting the leaf surface (WósciK, 2004). The presence of substances such as detergent Tween 20 or 80 (surfactant chemicals) is necessary to reduce the solution droplets' surface tension, which increases the adhesion area on the leaf surface (TAIZ and ZEIGER, 2010). Elements transfer at cell needs the passage of particles through the cuticle layer, which is usually cracked or broken due to the effect of wind on the leaves, allowing the particles to enter the skin that has cytoplasmic channels that help the passage of molecules as well as find spaces between the cells. Also, the presence of stomata, which is the pore, is an important outlet that helps penetrate nutrients into the leaf and the space between the cells. This phenomenon occurs with the property of diffusion (WóJcIK, 2004). The foliar absorption mechanism includes Surface absorption, Negative diffusion, and Active uptake by cells.

\section{Surface absorption}

The regression concentration is mainly responsible for penetration nutrients from the outside into the cell wall in the free spaces and then reaching into the cells (the cytosol), i.e., from the hydrophobic to the hydrophilic component and from the low to the high charge (ÖRDöG and MoLná, 2011)

\section{Negative diffusion}

The movement of biochemical and other atoms and molecules across the cell membrane is called negative diffusion. Unlike active transport, passive transport does not require the input of chemical energy but is driven by an increase in the system's introspection. The negative transfer rate depends on cell membrane permeability, which depends on the cell membrane's regularity and properties' lipids and proteins. The four main types of passive transport are spread, laxative, filtration, and osmotic (TAIZ and ZeIger, 2010). At the time of transpiration, the leaf's central tissue cells lose some water in transpiration, increasing its absorptive strength and withdrawing water from the adjacent cells, which increases the absorption by osmosis and removes moisture from neighboring cells. The stream reaches the vessel's wood absorption by the roots or gaps or skin cells. And then, the leaf's surface and absorption occur through the leaves (LAMBERs et al., 2008).

\section{Active uptake by cells}

Under the cuticle layer (skin cells), as the thickness of the cuticle does not impede the absorption of nutrient ions because of the occurrence of cracks in the layer of cuticle and the presence of cytoplasmic channels extending from skin cells to the area of the cutin, nutrients can enter into the cellular tissue. The process of nutrient absorption through the vegetative parts is similar to absorption across the roots. The elements move between cells and their outer environment based on the water potential difference (TAIZ and ZEIGER, 2010). The absorption process begins 


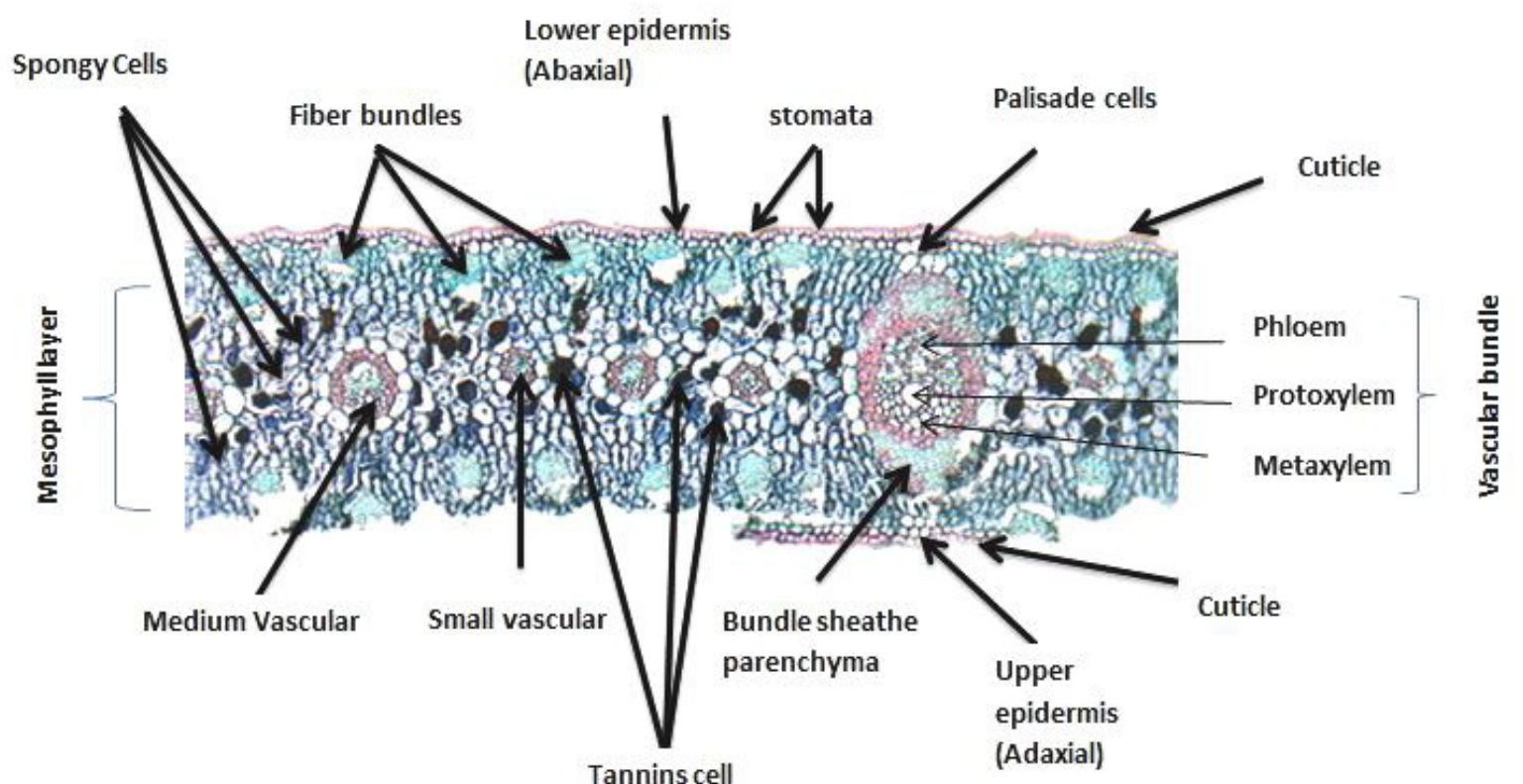

Fig. 3. Typical structure of cross-section to date palm leaflet. Photo by authors.

with the start of the spraying of nutrient solutions. When the leaves are wet, the guard cells' turgor pressure in the leaf increases with the nutrient solutions, leading to the stomata's opening. The permeability of the cuticle increased for nutrients. It penetrates by the pores present inside the cuticle and through small water channels that are also pathways for absorbing the nutrients (JONES and JEFF JACOBSEN, 2001).

\section{Essential aspects for spraying technique}

There are two essential aspects when using the spraying method on date palm: surfactants and the availability of chelating material.

\section{Surfactants}

Surfactants are usually utilized in pesticide definitions to improve a droplet arrangement (HoLloway and
STOck, 1990). Surfactants have a place with the dynamic surface operators having both hydrophilic and lipophilic gatherings. Such a structure can make "spans" between the fluid arrangement and lipophilic waxes (see Fig. 4) (SCHÖNHERR, 2001). In this way, surfactants decrease the leaf's surface tension, prompting an expansion in leaf wetting. Surfactants likewise bridge the gap between the air layer and the fluid and leaf surfaces, incrementally infiltrate solutes through the stomata, cuticular films, cell dividers, and the point of confinement the drying of beads (see Fig. 4, B) (WóJcIK, 2004).

\section{Chelates}

Chelates are intricate mixes comprised of a focal metal particle connected by a couple of organizing bonds with a ligand. Metal capacity to make chelates declines with the diminishing electric charge proportion to particle range (Tuteja and Singh Gill, 2013). Chelation encourages

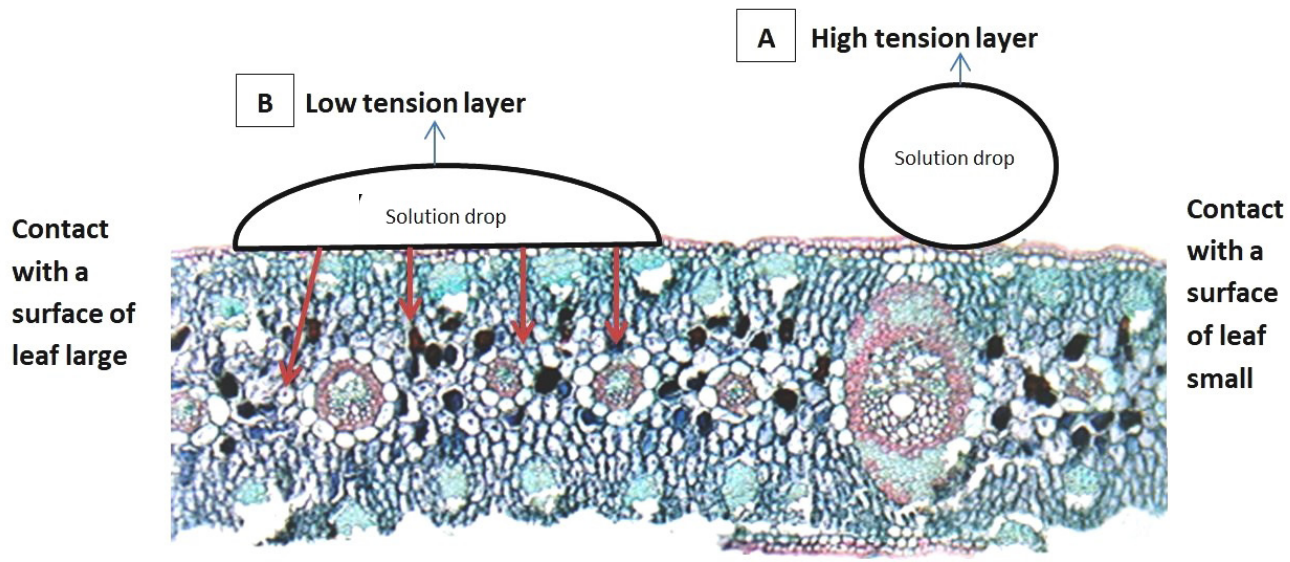

Fig. 4. Effect of surfactant on date palm leaflet surface (A) solution drop without surfactant, (B) solution drop with surfactant. Photo by authors. 
the versatility of molecular inside a plant. The utilization of chelated supplement frames, as a rule, does not build retention in connection to inorganic salts (TORABI et al., 2012). Thus, it appears that the impact of chelates on leaf capacity to take up nutrients identified with a few properties of a chelate, for example, a sub-atomic load of the mindboggling, separation consistent, and steadiness of the complex at different arrangement $\mathrm{pH}$ (KeLLER, 2004). The chelating substances are original mixes with low atomic loads that can shape complex components. Citric acid is one of the most important and widely available types of chelate (SHAREEF et al., 2017). Chelates are easily absorbed by the plant's roots and veins as organic matter, removing the positive charge of the nutrients and solves the negative charge and enter through the pores of the roots and leaves (Goli et al., 2012). The pores' charge is negative (micropositive charge) and will be established naturally within the pores and challenging to enter the plant. Easy to move inside the plant, simple to install, and assimilation inside the plant as organic matter. Under alkaline conditions, iron, zinc, magnesium, and copper are the best ways to supply micro-nutrients to the plant, compatible with a wide range of pesticides and liquid fertilizers as they do not interact with their constituents (mixed with dry and liquid substances) (BharathiraJa et al., 2016). Chelate cannot be lost from the soil because it is firmly bonded to soil particles' surfaces, and the natural chelate is better than an industrial chelate (SEKHON, 2003). One of the most important of these chelating materials is organic acids. The best way to use chelate to facilitate foliar fertilization is to mix it with the substance to be sprayed on the date palm in a correct proportion.

\section{Date palm responses to foliar fertilization}

The first attempt to use foliar spraying on date palm was during the 1989-1990 growing season in Egypt (AHMED et al., 1991). The researchers used magnesium sulfate as a fertilizer to overcome the shortage of magnesium in the sandy lands of the Bint Aisha fruit-bearing variety. In the growing season, 1994-1995, the same researcher AHMED and ABDEL HAMID (1997) experimented to identify the behavior of the date palm cultivar of Bint Aisha, which was grown in sandy soils under the influence of boric acid spray. The positive results obtained from both studies contributed to the launching of many experiments on the extent of date palm response to foliar spraying. The earliest attempt in Iraq was by ABAss et al. (2007), who used urea and iron application on Hillawi cultivar's productivity. Studies conducted during the past 30 years, either on adult date palm trees or on offshoots, especially those subjected to environmental stresses such as salinity and drought.

\section{Date palm responses to spray foliar of mineral nutrients}

Researchers have obtained many positive and clear indications that the date palm does not differ from other plants in response to foliar spraying. All these experiments recommended using their results and conducting other operations to develop the reality of date palm cultivation in the world (Table 1). Most of the nutrients used in feeding date palms are urea, phosphorus, potassium sulfate, potassium silicate, sodium silicate, and boric acid. As well as used whether NPK (20-20-20-1\% MgO) or NPK (20-20-20 + Fe-Mn-B-Zn-Mo-Cu) as indicated in Table 1, studies showed positive results in leaf area, fruit weight, and dates production.

\section{Date palm responses to spray foliar of chelated iron}

Chelated iron is widely used in feeding date palms in various ways, including foliar spraying. Iron is essential in regulating many enzymes, including peroxidase, catalase, and cytochrome oxidase (DE PAula et al., 2019). Iron in these compounds is of particular importance in oxidation reactions, the transfer of electrons in oxidation and reduction reactions, confirming its role in cell metabolism processes. And iron is essential in maintaining green matter inside the plant and the representation of nucleic acids and chloroplasts (DE PAULA et al., 2019). Several experiments were conducted, including iron, to improve the growth and production of dates are provided in Table 2 (ABAss et al., 2012; FAISAL et al., 2017; FAISAL et al., 2018).

\section{Date palm responses to spray foliar of bio-stimulants}

Agricultural biostimulants (ABs) incorporate differing definitions of compounds, substances, and other products, for example, microorganisms, trace elements, enzymes, plant growth regulators, and macroalgal separates that are applied to plants or soils to direct and upgrade the yield's physiological procedures, accordingly making them progressively proficient. "Agricultural biostimulants act on the physiology of the plant through different pathways to improve yields, quality, and post-harvest shelf-life/conservation," according to SHARma et al. (2014). Macroalgal ABs appear to impact respiration, photosynthesis, nucleic acid synthesis, and ion uptake (DU JARDIN, 2015). Several studies have used biostimulants to either reduce environmental impacts (АTTAH et al., 2016; Shareer et al., 2017; TAHA and Abood, 2018; Shareef, 2020) or to improve the growth and production of date palm (Altememe and Al-Sirdah, 2012; Al-Wasfy, 2013; Attaha and Al-Mubark, 2014; Al-Haiaj et al., 2020). These studies showed positive results in using biostimulants on date palms and rapid response by plants (see Table 3).

\section{Date palm responses to spray foliar of antioxidants}

Antioxidants participate in plant development flowering and organic product improvement through their positive activity on upgrading the biosynthesis of natural hormones, nutrient uptake, photosynthesis, biosynthesis of plant 


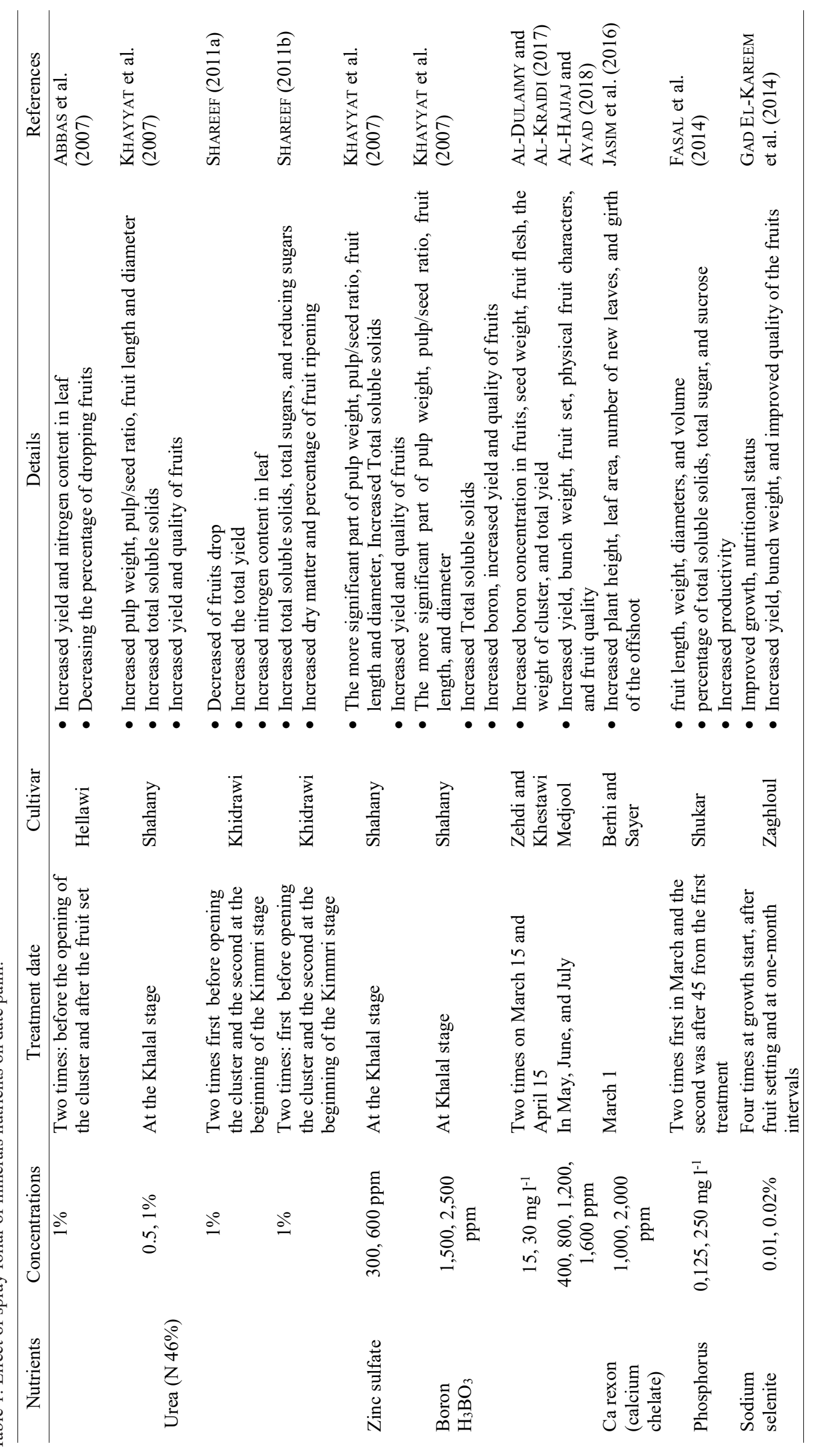




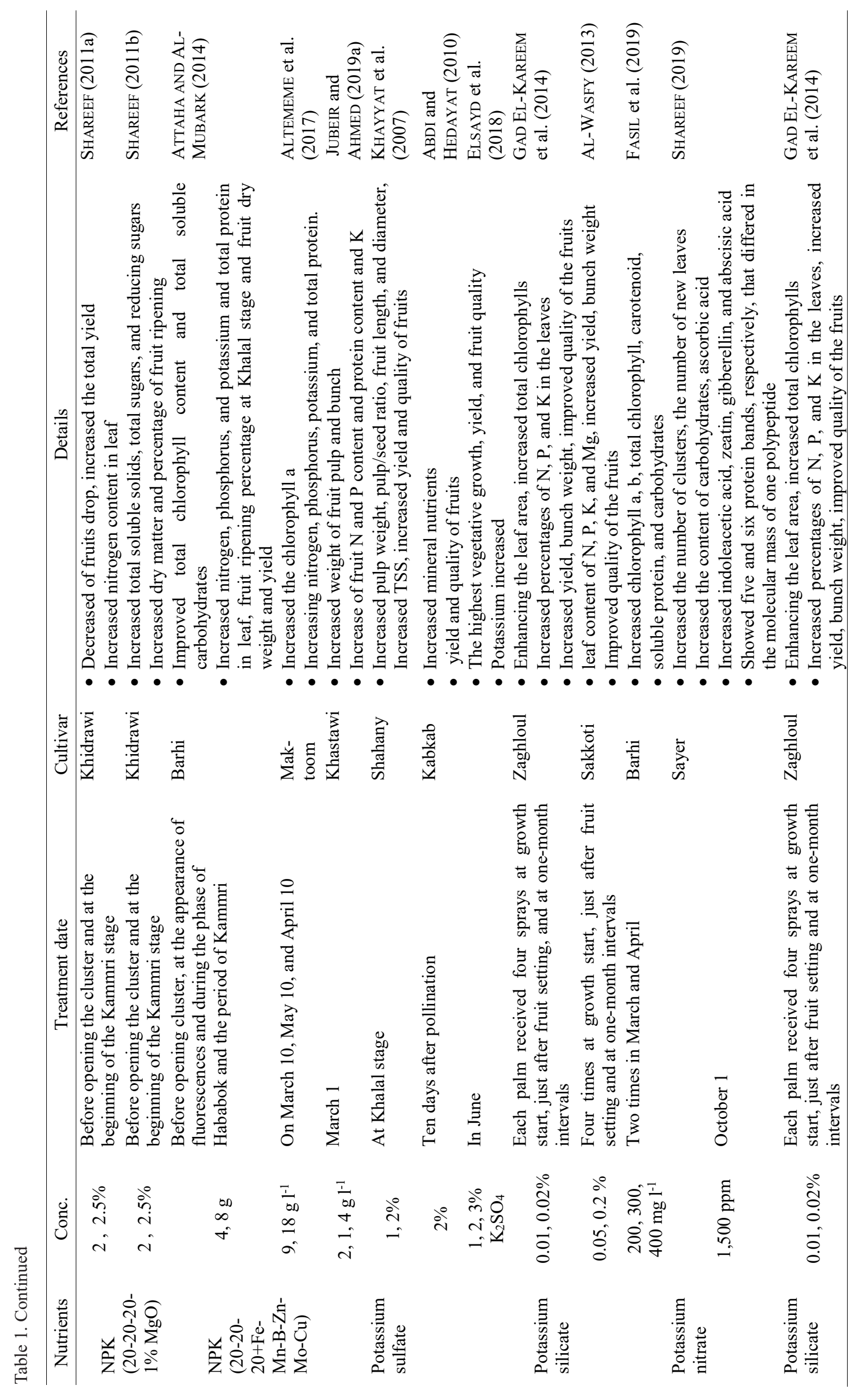


pigments, and sugars. Protecting the plant from biotic and abiotic stress increases antioxidant defense systems and reduces reactive oxygen species (MERwAD et al., 2015). Antioxidants such as organic acids, amino acids, and vitamins may assume a straightforward job in solving the problem of low yield through enhancing growth, nutritional status (DORRIA et al., 2012) such as date palm (FASAl et al., 2014; Shareef, 2016; Al-Dulaimy and Al Kraidi, 2017; ShareEF, 2019 ) (see Table 4).

\section{Date palm responses to spray foliar of nano-fertilization}

The use of nano-fertilizers in agriculture to increase crop yield increases interest due to their unique physicochemical properties. Nanotechnology is utilized as spray-based delivery systems in fruit crop nutrition (NASROLLAHZADEH et al., 2019). Nano-fertilizers (NFs) assume significant roles in expanding vegetative development, improving regenerative growth and flowering, and efficiency, item quality, and the time frame of realistic usability (ZAHEDI et al., 2020)which play very important roles in increasing vegetative growth, improving reproductive growth and flowering, thereby increasing productivity, product quality and ultimately increasing shelf-life and decreasing fruit waste. These nanomaterials, which are generally sprayed at low concentrations on trees at different time intervals and in frequent sessions, are also considered as growth stimulants. Macro- and micro-scale NFs such as zinc, boron, chitosan, and fertilizer nanocomposites such as $\mathrm{ZnFeMnB}$ (zinc, iron, manganese, boron). Nanomaterials generally sprayed at low concentrations at various time intervals, are additionally considered as development energizers for date palm, for example, nano-boron, (Super Fifty) seaweed extract, Optimus-Plus (5\% nitrogen, 30\% amino acids, and $3 \%$ organic nitrogen), Super-micro plus (Mn 0.7\%, Mg 6\%, Ca 6\%, Fe 4.5\%, Zn 8\%, K 3\%, P 3\%, N 5\%, Mo 0.1\%, B 0.65\%, and Cu 0.65\%) (REFAAI, 2014; Jubeir and Ahmed, 2019a; Jubeir and AhMed, 2019b; Ressan and Al-Tememi, 2019; Shareef et al., 2020) (see Table 5).

\section{Advantages and disadvantages of foliar fertilization to date palm}

Foliar fertilization has certain potential benefits; for example, the provision of fertilizers where the use of small amounts of fertilizer is appropriate compared to soil fertilization. Foliar fertilization can overcome the problems of soil factors that lead to the low utilization rate of manure, whether these factors lead to loss of fertilizer in the form of gas, or with irrigation water such as nitrogen, or determine the movement of sediment or fixing, such as phosphorus and microelements. The plant's rapid supply needs for elements during certain stages of growth, such as flowering or the beginning of the development of seeds and fruits, where root absorption of nutrients has often ceased. The earth's elements' interactions make absorption by the roots small, and boron and manganese 


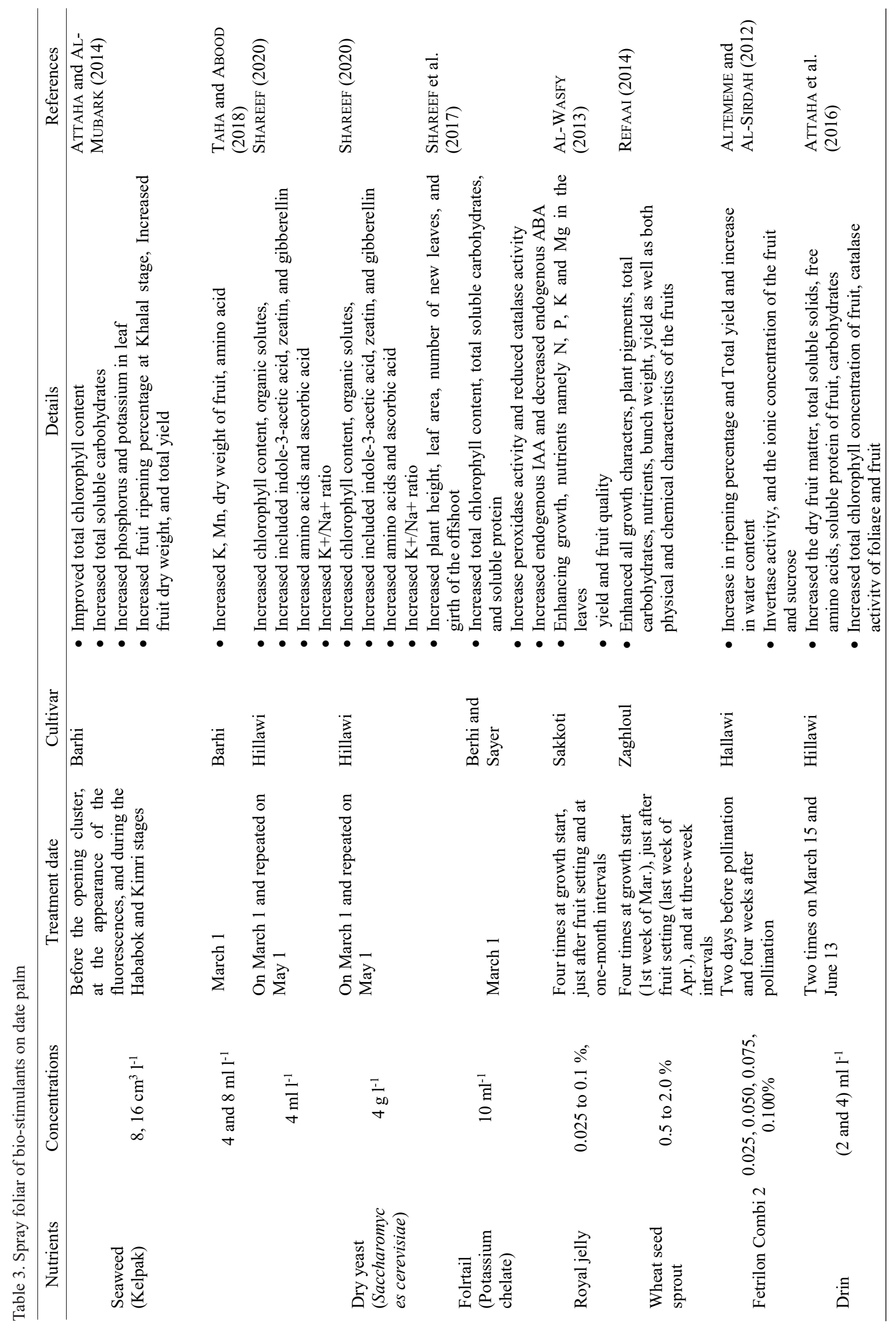




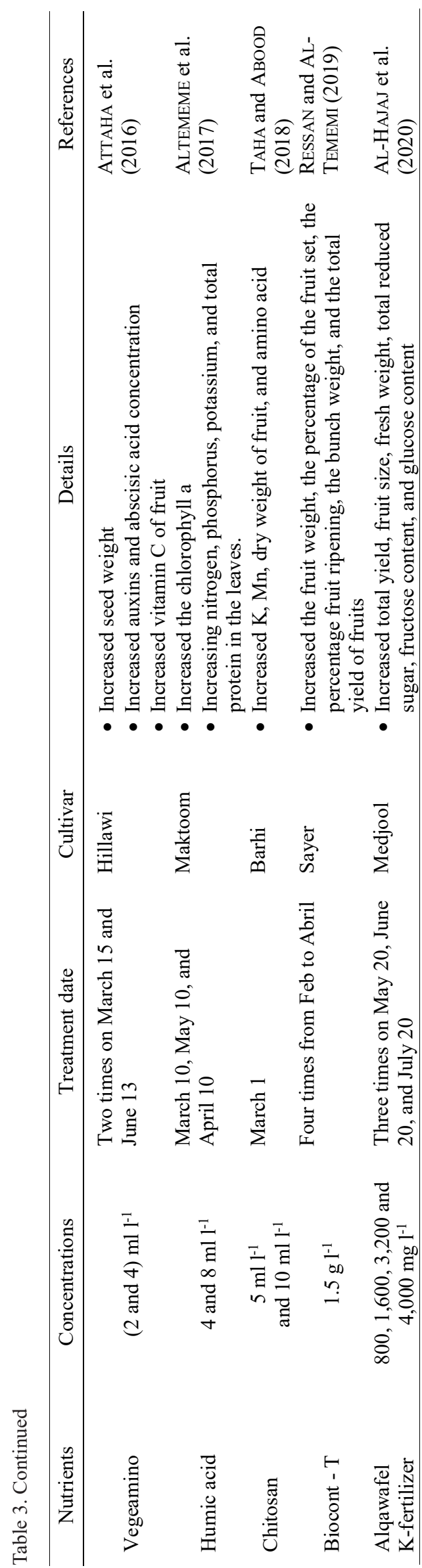

deficiency symptoms, iron, zinc, copper, and molybdenum will be apparent. While the use of foliar spray quickly compensates for the shortage of these elements. Ground fertilization is limited to roots only and needs time to reach the other organs, while foliar fertilization can get all parts of the plant for ease (MikKELSEN, 2007)

Foliar fertilization is $8-20$ times more efficient than ground fertilization, especially in the delivery of micronutrients. This nutrition has a high elasticity in the addition of fertilizers during the different growth stages, thus meeting the plant's nutrient requirements during different growth periods (FERNÁNDEZ and BROWN, 2013). The addition of nutrients to plants through spray-application ensures the nutrient is inputted directly into the plant and enhances plant tissue metabolism, reducing energy consumption. The foliar technique increases the potential for mixing nutrients with growth regulators, saving much effort and time (SALVAGiotTi et al., 2008).

Due to an inadequate understanding of the involved principles, foliar fertilization technology's full potential is not realized completely. According to the literature, knowledge gaps for developing and improving foliar fertilization strategies are apparent. However, valuable information about plant physiology, uptake mechanisms, fertilizer formulation, etc., are available. The use of foliar feeding is not without problems, and most of them depend on farmers through the use of chemicals fertilizer, especially urea, with higher concentrations than recommended. Seedlings or offshoots whose root group did not develop are still more at risk of higher levels of the elements because the plant metabolism cycle cannot get rid of excess metabolism by the roots, which leads to the toxicity of the plant. Researchers and those interested in date palm should not spray young palm trees (offshoots), especially in the first two years of cultivation, in addition to conducting soil and plant tests to determine the plant's needs for foliar fertilization. High temperature disrupts the plant's metabolism, and therefore the response may be malicious or harmful to the plant, and so on for the phenomena required for foliar fertilization. Not all symptoms of chlorosis leaves are due to a lack of nitrogen; it may be the opposite because yellowing also occurs to increase the concentration of ammonia in the plant or infection with a slight insect like a palm stalk borer. In total, foliar fertilization has great adaptive potential in modern date palm management.

\section{Conclusions}

Ultimately, the decision to use foliar fertilizers requires considerations of relative costs versus supply and demand factors. In general, when the farming system, soil type, or environmental factor is a severe obstacle to providing the required nutrients through the soil. In terms of efficacy and economics, the application of foliar fertilization can be a critical potential practice factor. Currently, after 30 years of applying foliar nutrients to date palms, this nutritional technique has proven suitable for date palms not only to fill deficiencies in some elements but to improve plant 


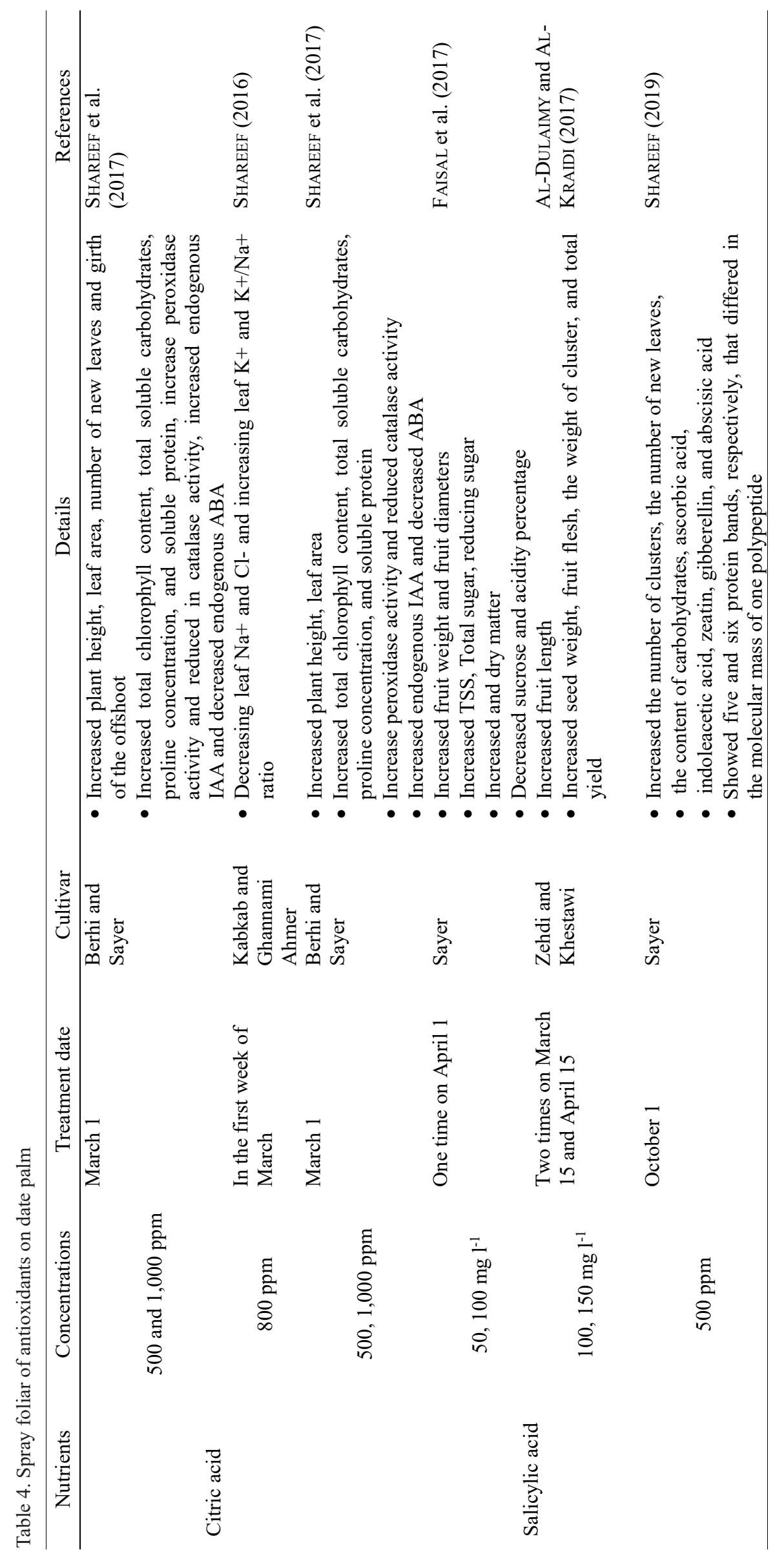




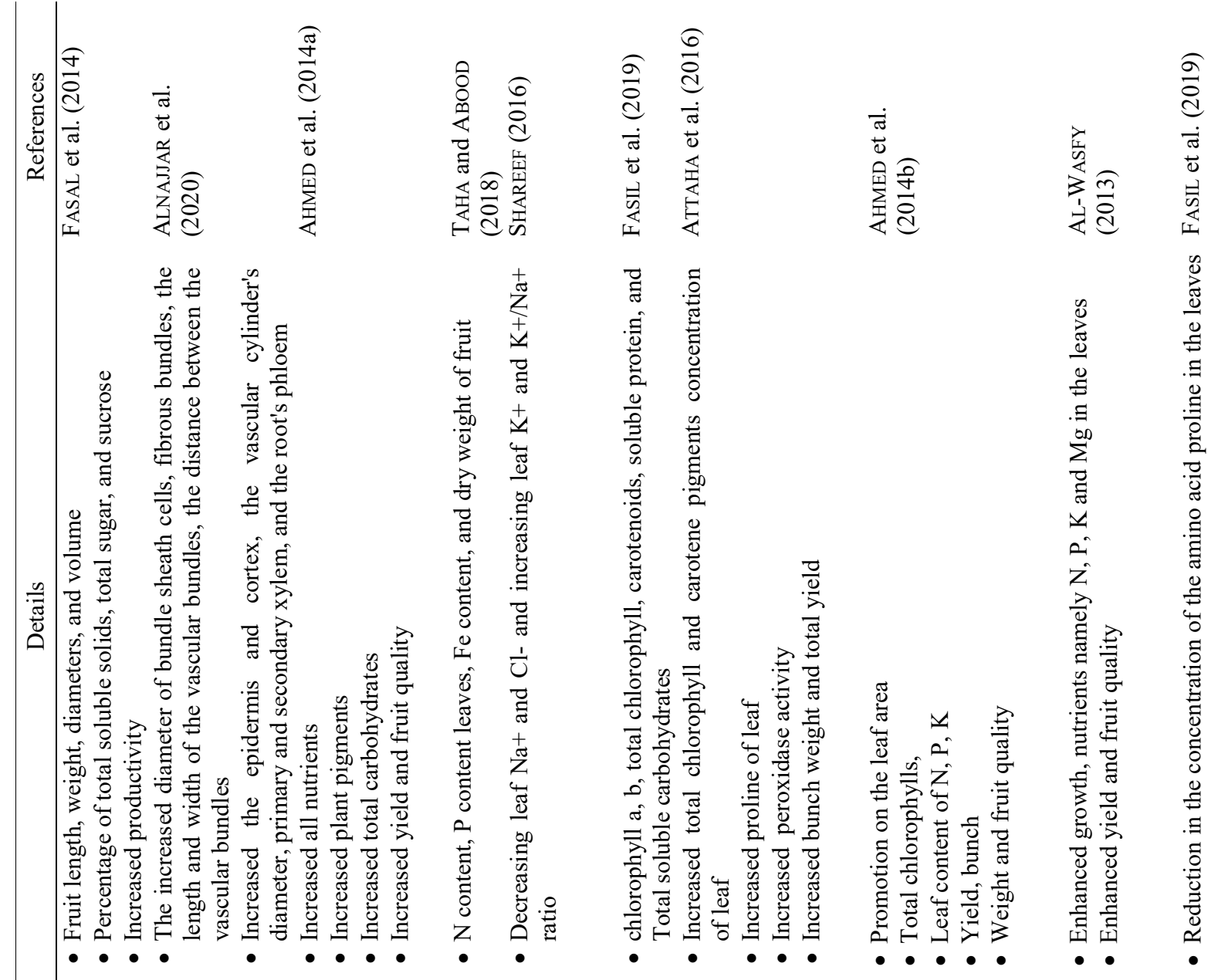

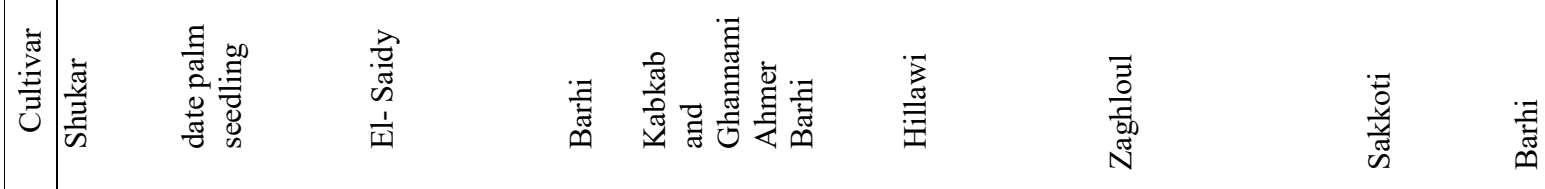

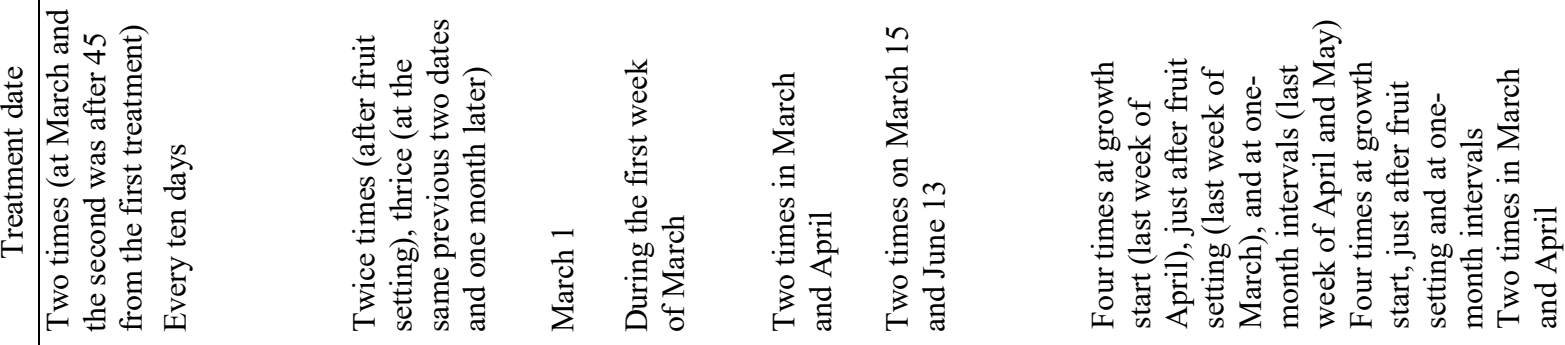

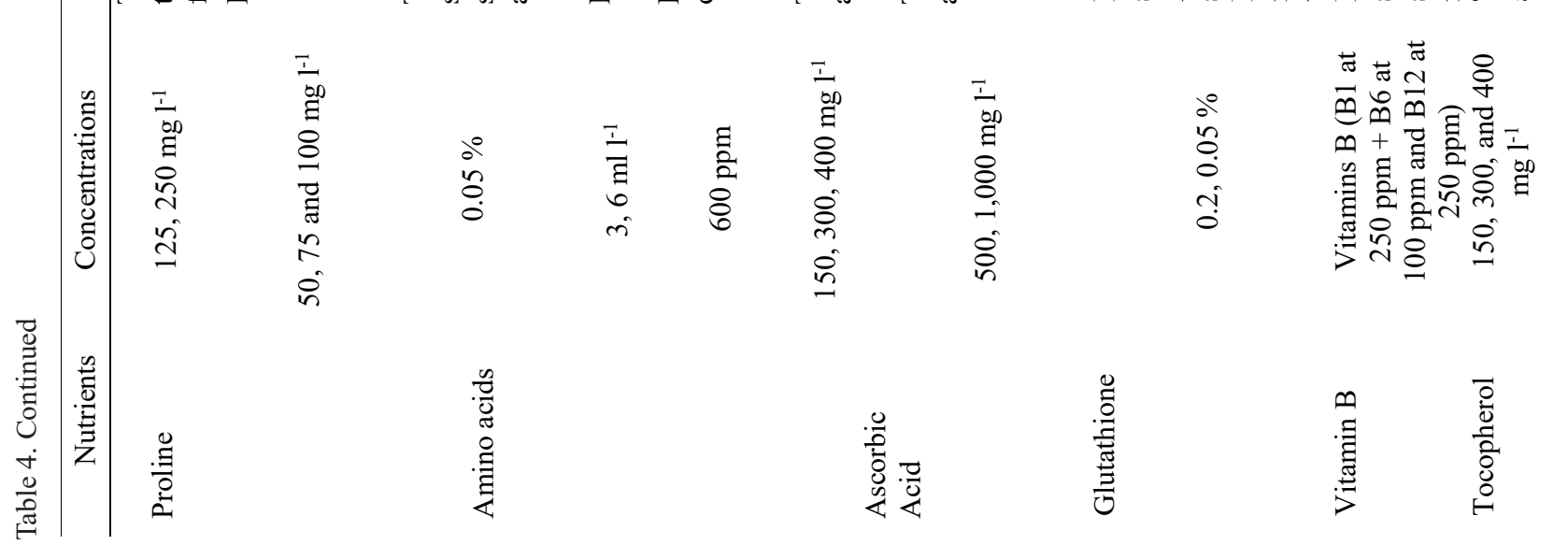




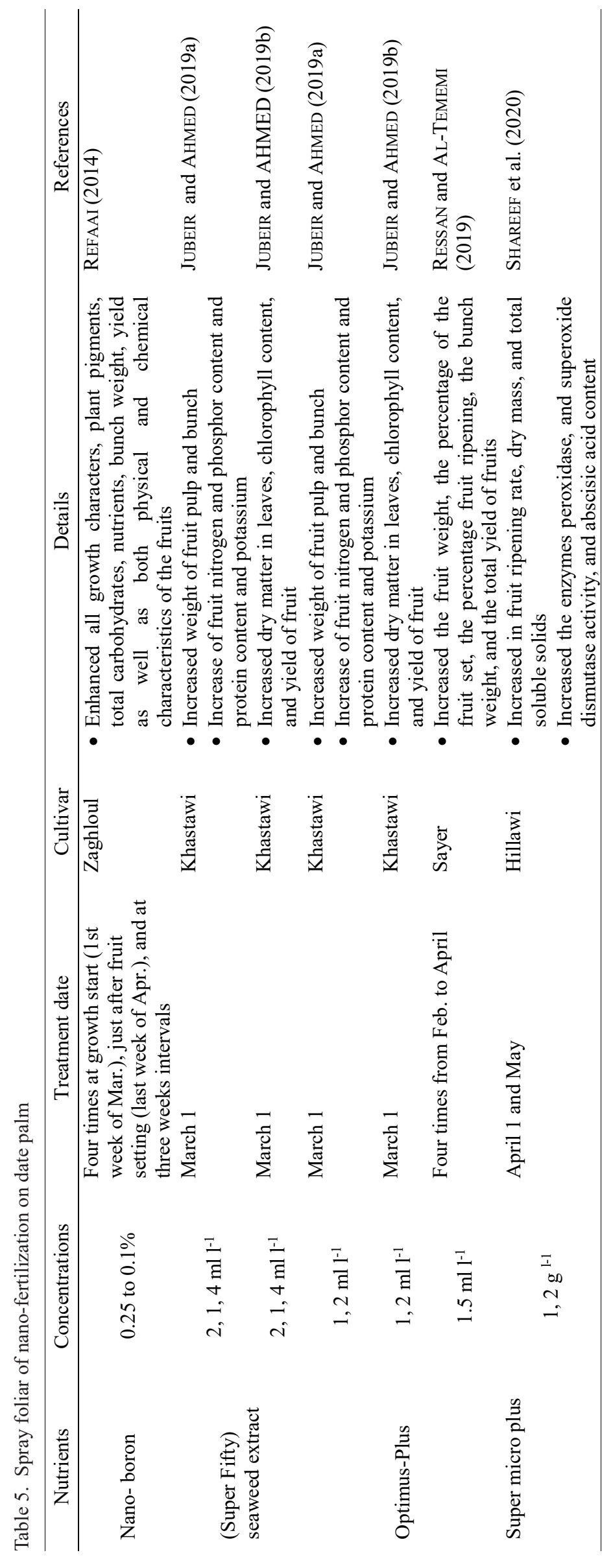


growth and increase production. Foliar nutrients do not mean relying primarily on foliar nutrition rather than soil fertilizing. Earth compost is essential for basic plant nutrition and an irreplaceable option in improving soil fertility and plant supply on the planet.

\section{Acknowledgements}

The authors are grateful to Professor Dennis V. Johnson of Cincinnati, Ohio, USA, for this manuscript's critical review and editorial enhancement. This work is directed by the scientific committee of the Date Palm Research Center, University of Basrah.

\section{References}

AbADIA, J., 1992. Leaf responses to iron deficiency - a review. Journal of Plant Nutrition, 15: 1699-1713.

Abass, K.I., Hameed, E.H., Al-Ramadan, A.A., 2012. Effect of chelated iron and benzyl- adenine on physiochemical characteristics and yield of date palm (Phoenix dactylifera L.) C.V. "Hellawi" Journal of King Abdulaziz University: Meteology, Environment and Arid Land Agricultural Sciences, 23 (1): 19-35. https://doi.org/10.4197/Met

Abass, K.I, TaAin, D.A., Wahid, A.M., 2007. Study the effect of nitrogen and iron application on productivity of date palm Phoenix dactylifera L. c.v. Hellawi. Journal of Basrah Researches (Sciences), 15 (3): 15-19.

Aвbas, K.I., 2004. Study of stomata number, concentration of chlorophyll and green area of leaflet in three varieties Kantar, Braim and Kassab of date palm. Basrah Journal for Date Palm Research, 3 (1-2): 60-65.

AbDi, G.H., Hedayat, M., 2010. Yield and fruit physiochemical characteristics of "Kabkab" date palm as affected by methods of potassium fertilization. Advances in Environmental Biology, 4 (3): 437-442.

Ahmed, F.F., Abdel Hamid, H.M., 1997. The behavior of date palm Bint Aisha to spray boron. Annals of Agricultural Sciences, 35 (2): 909-914.

Ahmed, F.F., Asi, K.J., Darwish, O.H., 1991. The response of date palm cultivar Bint Aicha in sandy lands to foliar spray with magnesium. Journal of Agricultural Research and Development, 13 (2): 707-723.

Ahmed, F.F., Ali, A.H., Abdalla, A.S., Omar, O.M.S., 2014a. Using some amino acids enriched with certain nutrients for improving productivity of El-Saidy date palms. World Rural Observations, 6 (2): 20-27.

Ahmed, F.F., Wasfy, E., Madian, M., Mohamed, A.A., 2014b. Fruiting of Zaghloul date palms in response to foliar application of the antioxidant glutathione. In Proceedings of the fifth international date palm conference.16-18 March 2014, Abu Dhabi, United Arab Emirates. Khalifa International Award Date Palm, p. 89-94.

Al-Dulaimy, R.M.H., Al-Kraidi, E.H.M., 2017. Effect of spraying with salicylic acid and boron in some yield characteristics and its components for date palm (Phoenix dactylifera L.) cvs. Zahdi and Khestawi. Anbar Journal of Agricultural Sciences, 15, Special issue: 268-278.
Al-Hajaj, H.S., Ayad, J.Y., Othman, Y.A., Abu-Rayyan, A., 2020. Foliar potassium application improves fruits yield and quality of 'Medjool' date palm. Fresenius Environmental Bulletin, 29 (3): 1436-1442.

Al-Hajuaj, H.S., Ayad, J.Y., 2018. Effect of foliar boron applications on yield and quality of Medjool date palm. Journal of Applied Horticulture, 20 (3): 181-188.

AL-Wasfy, M.M., 2013. Response of sakkoti date palms to foliar application of royal jelly, silicon and vitamins $b$. Journal of American Science, 9 (5): 315-321.

Al-Yahyai, R., Manickavasagan, A., 2012. An overview of date palm production. In Dates, production, processing, food, and medicinal values. Boca Raton: CR Press. 442 p. https://doi.org/10.1201/b11874

Alnajuar, M.A., Alpresem, W. F., Ibrahim, M.A., 2020. Effect of amino acid proline treatment on anatomical characteristics of leaves and roots of date palm seedlings Phoenix dactylifera L. developed under saline stress conditions. Plant Archives, 20 (1): 755-760.

Alnajuar, M., Alhamd, A., 2016. Anatomical comparative study of date palm Phoenix dactylifera 1. Leaves of dry, semidry and soft varieties. Jordan Journal of Agricultural Sciences, 12 (4): 1325-1331.

AlshaAl, T., El-Ramady, H., 2017. Foliar application: from plant nutrition to biofortification. Environment, Biodiversity \& Soil Security (EBSS), 1: 71-83. https://doi. org/10.21608/jenvbs.2017.1089.1006

Altememe, I., Al-Sirdah, A.S.M., 2012. The effects of fertilizer (Fetrilon Combi2) spraying and dates of application on chemical characteristics and yield of the date palm Phoenix dactylifera L. cv. Hillawi Ebtihaj. Basrah Journal of Date Palm Research, 11 (1): 1-24.

Altememe, Z.A.M., Ali, A.A., Shareef, M.H., Kadhim, A.Q., 2017. The physiological study of the effect of foliar spray of humic acid and compound fertilizers N.P.K on some chemical characteristics of date palm cultivar maktoom in the city of Karbala. Karbala Journal of Agriculture Sciences, 4 (1): 1-13.

Álvarez-Fernández, A., García-Laviña, P., Fidalgo, C., Abadía, J., Abadía, A., 2004. Foliar fertilization to control iron chlorosis in pear (Pyrus communis L.) trees. Plant and Soil, 263 (1-2): 5-15. https://doi.org/10.1023/ B:PLSO.0000047717.97167.d4

AtTAha, A.H.M., Al-Mubark, N.R.A., 2014. Effect of spraying seaweed extract Kelpak and NPK fertilizer on nitrogen, phosphorus, potassium and total protein concentrations of leaves and fruits of Phoenix dactylifera L., cv. Barhi. Journal of Basrah Researches (Sciences), 40 (1): 65-84.

Aтtaha, A.H.M., Huda, A.A, Muntaha, M.A., 2016. Effect of spraying vegeamino, drin and ascorbic acid on peroxidase and catalase enzymes activities in fruit, leaf and yield of Phoenix dactylifera L., c.v. Hillawi. Journal of Di-Qar University for Agriculture Research, 5 (2): 422-441.

Bharathiraja, B., Chakravarthy, M., Ranjith Kumar, R., Jayamuthunagai, J., Praveen Kumar, R., 2016. Integrated biorefinery for bioenergy and platform chemicals. In Platform chemical biorefinery: future green 
chemistry. Amsterdam: Elsevier, p. 417-435. https://doi.org/10.1016/B978-0-12-802980-0.00022-5

Bringe, K., Schumacher, C.F.A., Schmitz-Eiberger, M., Steiner, U., Oerke, E.C., 2006. Ontogenetic variation in chemical and physical characteristics of adaxial apple leaf surfaces. Phytochemistry, 67 (2): 161-170. https:// doi.org/10.1016/j.phytochem.2005.10.018

Comerford, N.B., 2005. Soil factors affecting nutrient bioavailability. In Nutrient acquisition by plants. Ecological Studies, 181. Berlin, Heidelberg: Springer, p. $1-8$.

Davoodi, D., Majidi, E., KhoshKam, S., 2002. Some morphological and anatomical aspects of date palm (Phoenix dactylifera L.) somatic embryogenesis in tissue culture. Journal of Agricultural Science and Technology, 4: 63-71.

De Paula, L.F.A., Kolb, R.M., Porembski, S., Silveira, F.A.O., Rossatto, D.R., 2019. Rocks and leaves: can anatomical leaf traits reflect environmental heterogeneity in inselberg vegetation? Flora: Morphology, Distribution, Functional Ecology of Plants, 250: 91-98. https://doi. org/10.1016/j.flora.2018.11.020

Doaigey, A.R., Al-Whaibi, M.H., SiddiQui, M.H., Al SAhli, A.A., El-ZAIDY, M.E., 2013. Effect of GA3and 2,4-D foliar application on the anatomy of date palm (Phoenix dactylifera L.) seedling leaf. Saudi Journal of Biological Sciences, 20 (2): 141-147. https://doi.org/10.1016/j. sjbs.2012.12.001

Domínguez, E., Cuartero, J., Heredia, A., 2011. An overview on plant cuticle biomechanics. Plant Science, 181: 77-84. https://doi.org/10.1016/j.plantsci.2011.04.016

Dordas, C., 2008. Role of nutrients in controlling plant diseases in sustainable agriculture: A review. Agronomy for Sustainable Development, 28 (1). 33-46. https://doi. org/10.1007/978-90-481-2666-8_28

Dorria, A.M., Ashour, N.E., Mostafa, E.A.M., Saleh, M.M.S., HASSAN, H.S.A., 2012. Yield and fruit quality of Amhat date palms as affected by spraying some vitamins Journal of Applied Sciences Research, 8 (10): 4922-4926.

Du JARDIN, P., 2015. Plant biostimulants: definition, concept, main categories and regulation. Scientia Horticulturae, 196: 3-14. https://doi.org/10.1016/j.scienta.2015.09.021

Elsayd, I.A.E.-R., El-Merghany, S., Zaen El - Dean, E.M.A., 2018. Influence of potassium fertilization on Barhee date palms growth, yield and fruit quality under heat stress conditions. Journal of Plant Production, 9 (1): 73-80. https://doi.org/10.21608/jpp.2018.35258

Fageria, N.K., Filho, M.P.B., Moreira, A., Guimarães, C.M., 2017. Foliar fertilization of crop plants. Journal of Plant Nutrition, 32 (6): 1044-1064. https://doi. org/10.1080/01904160902872826

Faisal, H.A., Authafa, Q.J., Abdulla, A.S.A., 2018. The effect of foliar spray of potassium nitrate and chelated iron on some physiological and chemical characteristics for date palm Phoenix dactylifera L. Nersy c.v. Basrah Journal for Date Palm Research, 17 (1-2): 79-91.

Faisal, H.A., АTHAFAH, Q.J., Wahid, A.H.A., 2017. Effect of spraying iron chelated and salicylic acid on some characteristics of date palm (Phoenix dactylifera L.) Sayer cultivar. Kufa Journal for Agricultural Science, 9 (2): $1-13$
Fasal, H.A., AbDulwahid, A.H., Authafa, Q.J., 2014. Effect of spray phosphorus and proline on some physical and chemical characteristics and production for date palm Phoenix dactylifera L. Shuker cultivar Hassan. Basrah Jurnal for Date Palm Research, 13 (1-2): 2-8.

FASIL, H.A., ABBAS, M.F, JAFEER, O., 2019. Effect of spraying with ascorbic acid, tocopherol, and silicon in some physiological characteristics of date palms offshoots Phoenix dactylifera L. cv. Barhi growing in salinity soil. Basrah Journal of Date Palm Research, 18 (1): 35-55.

Fernadéz, V., Sotiropoulus, T., Brown, P., 2015. Foliar fertilization: scientific principles and field practices. Statewide Agricultural Land Use Baseline. Paris, France: IFA. $140 \mathrm{p}$.

FernándeZ, V., Brown, P.H., 2013. From plant surface to plant metabolism: the uncertain fate of foliar-applied nutrients. Frontiers in Plant Science, 4 : 1-5. https://doi. org/10.3389/fpls.2013.00289

Gad El-Kareem, M.R., Abdel Aal, A.M.K., Mohamed, A.Y., 2014. The synergistic effects of using silicon and selenium on fruiting of Zaghloul date palm (Phoenix dectylifera L.). International Scholarly and Scientific Research \& Innovation, 8 (3): 259-262.

Goli, M.B., Pande, M., Bellaloui, N., 2012. Effects of chelating agents on protein, oil, fatty acids, and minerals in soybean seed. Agricultural Sciences, 3 (4): 517-523. https://doi.org/http://dx.doi.org/10.4236/ as. 2012.34061

Holloway, P., Stockd, J., 1990. Factors affecting the activation of foliar uptake of agrochemicals by surfactants. In KARSA, D.R. (ed.). Industrial application of surfactants II.: the proceedings of a symposium. Special publication, no. 77. London: Royal Society of Chemistry, p. 303-337.

IBRAHIM, K.M., 2018. Integrating date palm biotechnology with community, a review. Iraqi Journal of Biotechnology, 17: $1-12$.

Jasim, A. M., Abbas, M. F., Shareef, H. J., 2016. Calcium application mitigates salt stress in date palm (Phoenix dactylifera L.) offshoots cultivars of Berhi and Sayer. Acta Agriculturae Slovenica, 107 (1): 103-112. https://doi.org/10.14720/aas.2016.107.1.11

Jones, C., JefF JACOBSEn, M., 2001. Plant nutrition and soil fertility. Nutrient Management Module No. 2. Montana State University Extension Service. Publication 4449-2. 11 p. https://doi.org/10.1007/s007690000247

JubeIR, S.M., AHMED, W.A., 2019a. Effect of nano fertilizers and application methods to yield characteristics of date palm. Plant Archives, 19 (1): 1881-1886.

JubeIR, S.M., AHMED, W.A., 2019b. Effect of nanofertilizers and application methods on vegetative growth and yield of date palm. Iraqi Journal of Agricultural Sciences, 50 (1): $267-274$.

KelLeR, C.P., 2004. Long-term inhibition by auxin of leaf blade expansion in bean and arabidopsis. Plant Physiology, 134 (3): 1217-1226. https://doi.org/10.1104/pp.103.032300

Khayyat, M., Tafazoli, E., Eshghi, S., Rajaee, S., 2007. Effect of nitrogen, boron, potassium and zinc sprays on yield and fruit quality of date palm. American-Eurasian Journal of Agricultural \& Environmental, 2 (3): 289-296. 
Lambers, H., Chapin, F.S., Pons, T.L., 2008. Mineral nutrition. In Plant physiological ecology. New York, NY: Springer, p. 255-320. https://doi.org/10.1007/978-0-38778341-3

Lequeu, J., Fauconnier, M.L., Chammaï, A., Bronner, R., BLÉE, E., 2003. Formation of plant cuticle: evidence for the occurrence of the peroxygenase pathway. Plant Journal, 36 (2): 155-164. https://doi.org/10.1046/j.1365313X.2003.01865.X

Lobo, M. G., Yahia, E.M., Kader, A.A., 2014. Biology and postharvest physiology of date fruit. In SidDiQ, M. Salah, M.A., Adel, A.K. (eds). Dates: postharvest science, processing technology and health benefits. First edition. Chichester, West Sussex, Oxford: John Wiley \& Sons, Ltd. 311 p.

Merwad, M.A., Eisa, R.A., Mostafa, E.A.M., 2015. Effect of some growth regulators and antioxidants sprays on productivity and some fruit quality of Zaghloul date palm. International Journal of ChemTech Research 8 (4): 1430-1437.

MikKelsen, R.L., 2007. Managing potassium for organic crop production. HortTechnology, 17 (4): 455-460. https://doi. org/10.21273/horttech.17.4.455

Nasrollahzadeh, M., Sajadi, M.S., Atarod, M., SajJadi, M., IsAaBADI, Z., 2019. Types of nanostructures. In Nasrollahzadeh, M. An introduction to green nanotechnology. Interface Science and Technology, 28. Amsterdam: Elsevier Science Publishers, p. 29-80.

Obiremi, E.O., Oladele, F.A., 2001. Water conserving stomatal systems in selected Citrus species. South African Journal of Botany, 67 (2): 258-260. https://doi. org/10.1016/S0254-6299(15)31127-3

OOSTERHUIS, D. (ed.), 2009. Foliar fertilization: mechanisms and magnitude of nutrient uptake. Paper for the Fluid Fertilizer Foundation meeting in Scottsdale, Arizona. February 15-17, 2009. Fayetteville: University of Arkansas. [online]. [cit.2020-05-13].

ÖrdöG, V., Molnár, Z., 2011. Plant physiology. Az Agrármérnöki MSc szak tananyagfejlesztése. TÁMOP4.1.2-08/1/A-2009-0010 projekt. [online]. [cit. 2020-0620]. http://www.esalq.usp.br/lepse/imgs/conteudo/PlantPhysiology-by-Vince-Ordog.pdf

RefaAi, M.M., 2014. Response of Zaghloul date palms grown under Minia region conditions to spraying wheat seed sprout extract and nano- boron. Stem Cell, 5 (4): 22-28. https://doi.org/10.1017/CBO9781107415324.004

Ressan, S, H., Al-Tememi, H.H., 2019. Study of evaluating the efficiency of biological and Nano-fertilizers treatments and their addition methods in some the physiological and productive characteristics of date palm Phoenix dactlifera L. Basrah Journal for Date Palm Research, 18 (2): 84 101.

Salvagiotti, F., Cassman, K.G., Specht, J.E., Walters, D.T., WeIss, A., 2008. Nitrogen uptake, fixation and response to fertilizer N in soybeans. A review. Agronomy \& Horticulture — Faculty Publications, 133. http:// digitalcommons.unl.edu/agronomyfacpub/133

SCHŐNHERR, J., 2001. Cuticular penetration of calcium salts: effect of humidity, anions and adjuvants. Journal of Plant Nutrition and Soil Science, 164: 225-231.
SChÖNHERR, J., SCHREIBER, L., 2004. Size selectivity of aqueous pores in astomatous cuticular membranes isolated from Populus canescens (Aiton) Sm. leaves. Planta, 219 (3): 405-411. https://doi.org/10.1007/s00425-004-1239-0

SekHon, B.S., 2003. Chelates for micronutrient nutrition among crops. Resonance, 8 (7): 46-53. https://doi. org/10.1007/BF02834402

ShareEF, H.J., Jasim, A.M., AbBaS. M.F., 2017. Molecular analysis of anti-salinity compounds on date palm offshoots (Phoenix dactylifera L.) cultivars using RAPD. Journal of Environmental Science, 6: 61-71.

SHAREEF, H.J., 2011a. Effect of spraying with urea and NPK on production of date palm Phoenix dactylifera L. cv. Khidrawi. Basrah Journal for Date Palm Research, 10 (1): 34-39.

SHAREEF, H.J., 2011b. Effect of spraying with urea and NPK on some chemical characteristics and ripening of date palm fruits Phoenix dactylifera L. cv. Khidrawi. Basrah Journal Research (Sciences), B15 (4): 13-25.

SHAREEF, H.J., 2016. Role of antioxidants in salt stress tolerant of date palm offshoots (Phoenix dactylifera L.) female and male cultivars. International Journal of Current Agricultural Research, 3: 182-186.

ShareEF, H.J., 2019. Salicylic acid and potassium promote flowering through modulating the hormonal levels and protein pattern of date palm Phoenix dactylifera L. Sayer offshoots. Acta Agriculturae Slovenica, 114 (2): 231-238. https://doi.org/10.14720/aas.2019.114.2.8

ShareEF, H.J., 2020. Organic fertilizer modulates IAA and ABA levels and biochemical reactions of date palm Phoenix dactylifera L. Hillawi cultivar under salinity conditions. Asian Journal of Agriculture and Biology, 8 (1): 24-30. https://doi.org/10.35495/ajab.2019.02.062

Shareef, H.J., Al-Yahyai, R., Omar, A.E., Barus, W.A., 2020. Foliar nano-fertilization enhances fruit growth, maturity, and biochemical responses of date palm. Canadian Journal of Plant Science. In press. https://doi. org/10.1139/cjps-2020-0081

Sharma, H.S.S., Fleming, C., Selby, C., Rao, J.R., MarTIN, T., 2014. Plant biostimulants: a review on the processing of macroalgae and use of extracts for crop management to reduce abiotic and biotic stresses. Journal of Applied Phycology, 26 (1): 465-490. https://doi. org/10.1007/s10811-013-0101-9

ТАна, F.H., АвооD, M.R., 2018. Influence of some organic fertilizers on date palm CV. Barhi. Iraqi Journal of Agricultural Sciences, 49 (4): 632-638.

TAiz, L., Zeiger, E., 2010. Plant physiology. Fifth edition. Sunderland, Mass.: Sinauer Associates. 782 p.

Torabi, M., Mokhtarzadeh, A., Mahlooji, M., 2012. The role of hydroponics technique as a standard methodology in various aspects of plant biology researches. In Hydroponics - a standard methodology for plant biological researches. Rijeka: InTech, p. 113-134.

Tuteja, N., Singh Gill, S. 2013. Plant acclimation to environmental stress. Heidelberg: Springer. https://doi. org/10.1007/978-1-4614-5001-6 
WóscIK, P., 2004. Uptake of mineral nutrients from foliar fertilization. Journal of Fruit and Ornamental Plant Research, $12: 201-218$.

Xu, C.Y., Salih, A., Ghannoum, O., Tissue, D.T., 2012. Leaf structural characteristics are less important than leaf chemical properties in determining the response of leaf mass per area and photosynthesis of Eucalyptus saligna to industrial-age changes in $\left[\mathrm{CO}_{2}\right]$ and temperature. Journal of Experimental Botany, 63 (16): 5829-5841. https://doi. org/10.1093/jxb/ers231

Zahedi, S. M., Karimi, M., Teixeira Da Silva, J.A., 2020. The use of nanotechnology to increase quality and yield of fruit crops. Journal of the Science of Food and Agriculture, 100 (1): 25-31. https://doi.org/10.1002/ jsfa. 10004

ZAID, A., Hughes, H., 1996. In vitro hardening of date palm
(Phoenix dactylifera L.) plantlets: V. Leaf anatomy of in vitro polyethylene glycol-treated and greenhouse plants of date palm. In Proceedings of the third symposium on date palm in Saudi Arabia. January 17-20, 1993. Data Palm Research Center, King Faisal University. Riyiadh: Mars Pub. House, p. 145-152.

Zaid, A., Arias-JimÉneZ, E.J., 2002. Date palm cultivation. FAO Plant and Protection Papers, 156. Rome: Food and Agricultural Organization of the United Nations. 292 p.

Zhang, Q., Brown, P.H.,1999. The mechanism of foliar zinc absorption in pistachio and walnut. Journal of the American Society for Horticultural Science, 124 (3): 312317. https://doi.org/10.21273/jashs.124.3.312

Received July 6, 2020 Accepted November 30, 2020 